\section{Daniel Paullis og Johan Huusmans stik fra Skånske Krig 1675-1679}

\section{Af afdelingsbibliotekar Bjørn Westerbeek Dahl}

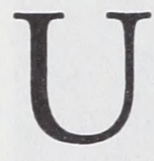
nder Skånske Krig 1675-79 udgav den dygtige københavnske forlægger Daniel Paulli en række kobberstukne kort og prospekter af de vigtigste begivenheder fra krigsskuepladserne i Nordtyskland og Skånelandene.

Kobberstikkene er overordentligt værdifulde som historiske kilder til krigens gang, og de udgør en fin parallel til den svenske generalkvartermester Erik Dahlbergs kendte tegninger fra krigen'.

For samtiden repræsenterede Paullis stik det første danske forsøg på at udgive en krigsreportage $\mathrm{i}$ billeder, og $\mathrm{i}$ modsætning til Dahlbergs tegninger, der først blev udgivet i dette århundrede, kom de tilmed til at præge samtidens opfattelse af begivenhederne ved at blive genoptrykt og kopieret i flere betydningsfulde værker.

\section{Udgiveren}

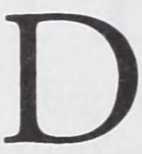

aniel Paulli var født i Rostock i

1640 som søn af Christian den 4.s livlæge, botanikeren Simon Paulli, men blev i 1664 kaldt til København for at videreføre driften af datidens største $\mathrm{k} ø$ benhavnske boglade, der tilhørte Helvig Petri Moltke, enke efter Joachim Moltke, der var død samme år. Det mislykkedes på grund af uoverensstemmelser med enken, men Daniel Paulli valgte alligevel at slå sig ned i København, hvor han året efter oprettede sin egen boghandel på hjørnet af
Skindergade og Fiolstræde (Matr. 1689/12 A, svarende til nutidens gadenummer 32 ). Desuden havde han et udsalg på Børsen. I 1672 begyndte han at udsende en avis, "Extraordinaire Relation", der byggede på nyheder, indhentet fra Hamburgerpressen. Han påbegyndte imidlertid snart efter en selvstændig bladudgivelse med originale artikler, "Extraordinaire Maanedlige Relationer", der senere blevet karakteriseret som Danmarks ældste avis ${ }^{2}$.

Daniel Paulli var ikke blot avisudgiver, men han fungerede tillige som bogforlægger i stor stil, bl. a. forberedte han en illustreret bibeludgave med pragtudstyr, hvoraf kun et prøvetryk nåede at udkomme før Paullis tidlige død i 1684.

Hans "næse" for publikums ønsker var god, og han kunne under Skånske Krig (1675-79) tilbyde sine avisabonnenter hurtige og pålidelige efterretninger om krigens gang, som han havde fået direkte fra meddelere i hær og flåde. Tilmed kunne Paulli hurtigt supplere sin nyhedsreportage med adskillige artikler om de skånske landsdeles - og særligt byernes historie. Alt $\mathrm{i}$ alt et nyhedstilbud af næsten moderne format ${ }^{3}$. Her skal imidlertid kun omtales hans forsøg på at udgive billeder fra krigen.

\section{Kobberstikkene}

T ugeavisen "Extraordinaire Relation" med tillægget "Extraordinaire Oeresundische Relation" kunne man allerede den 12. august 1676 finde en annonce, der adviserede læserne om, at man hos kobberstikkeren Johan Huusman på hjørnet af Vor Frue Kirkegård og Store Kannikestræde kunne købe "En sandfærdig Afbildning af det netop afholdte søslag mellem de kongelige danske og svenske flåder den 1. juni” [Slaget ved Øland]. 


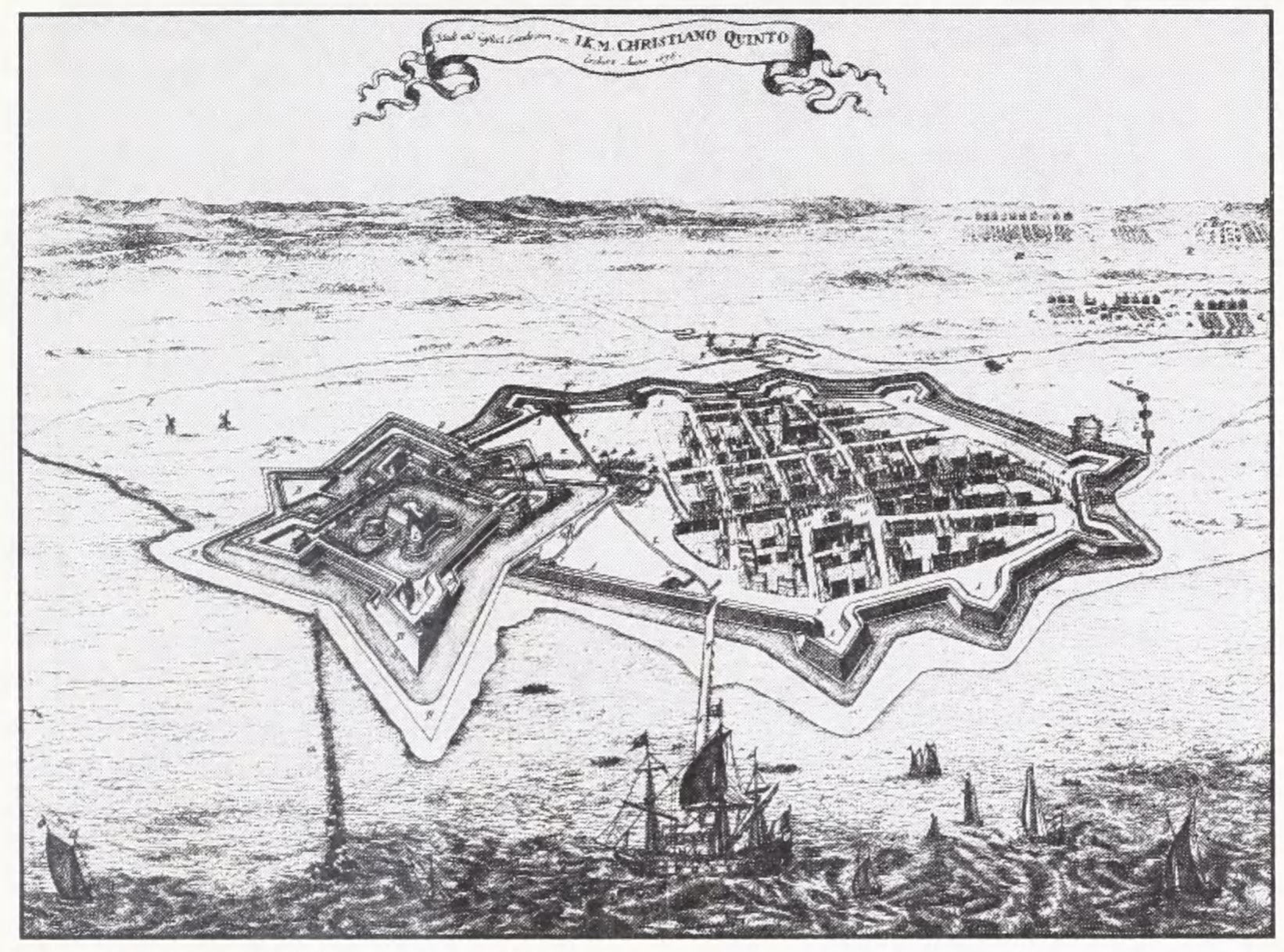

Prospekt af Landskrona, 1676. Paulli/Huusman.

Annoncen fortalte samtidigt, at man havde en "curiøs og accurat" afbildning af fæstningerne Landskrona, Helsingborg og andre skånske fæstninger i produktion, og at disse snarest - ligesom en kort beskrivelse - ville være at finde til salg hos Daniel Paulli.

En uge senere, 19. august 1676, annonceres så udgivelsen af "det nøjagtige prospekt af byen og kastellet Landskrona”, og snart derefter forventedes en tilsvarende plan over Kristianstad at være færdig tillige med en kort beskrivelse af erobringen af de to byer.

Daniel Paulli var tidligt på færde, for Landskrona var blevet erobret den 3. august og Kristianstad den 15. i samme måned, altså ganske få dage før avisannoncen.
Det hele gik meget hurtigt og åbenbart hurtigere end beregnet, for allerede mandag den 21 . kunne Paulli meddele sine læsere, at man ville kunne fă fat $\mathrm{i}$ planen af Kristianstad samme aften.

Derimod trak udgivelsen af stikket af Helsingborg, der var erobret allerede 3. juli, ud, og det lader til, at Paulli har prioriteret aktualiteten højere end kronologien. Men den 2. september fortæller Paulli, at grundridset var under udarbejdelse og ville kunne erhverves inden for otte dage. Hvornår det præcist blev udgivet, vides ikke, for herefter optræder en overraskende tavshed om billedreportagerne: Først af en notits den 24. oktober fremgår det, at der nu arbejdes på et kort over over Vänersborg, som Ulrik Frederik Gyldenløve havde erobret den 26. 


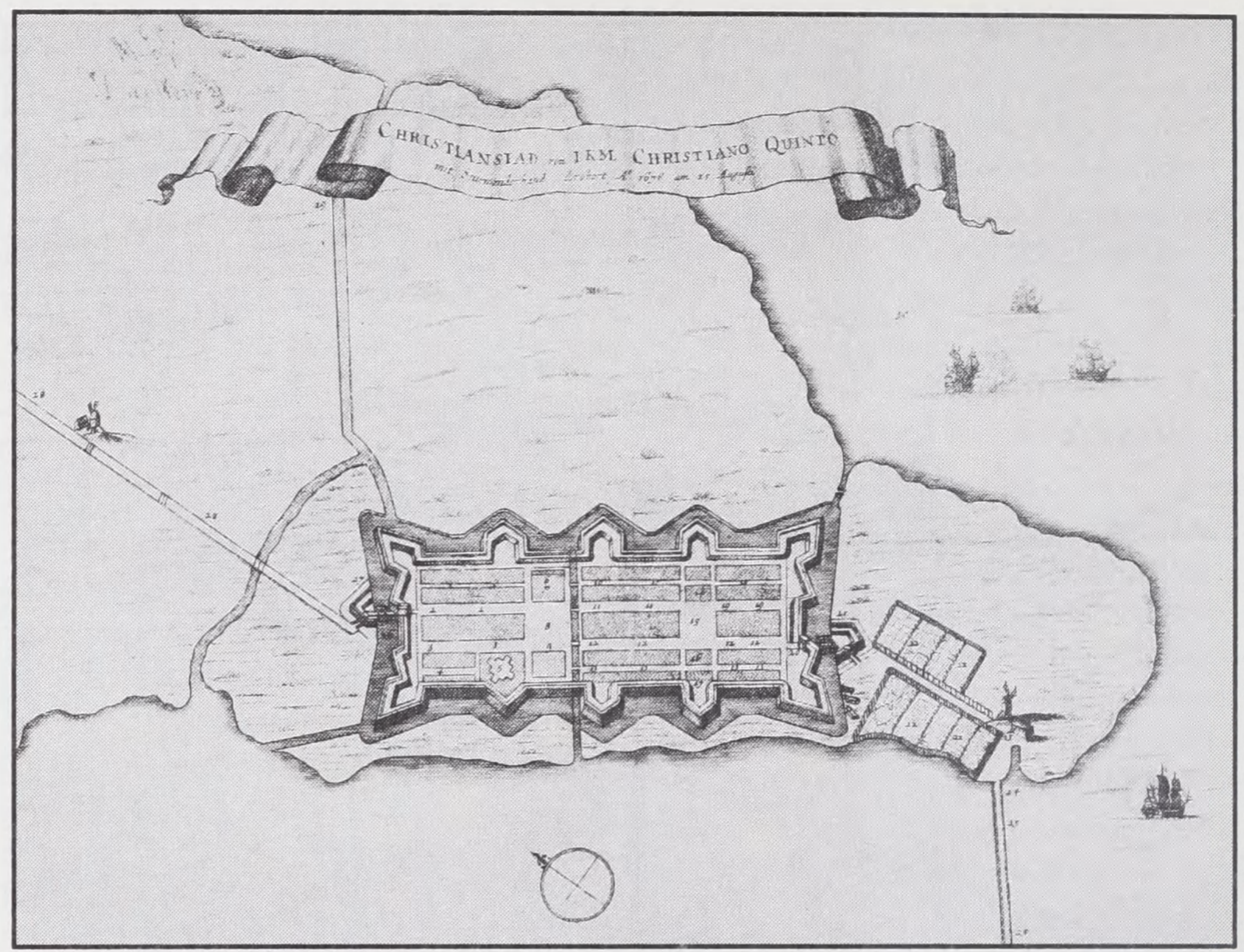

Grundrids af Kristianstad, 1676. Paulli/Huusman.

juni 1676. Samtidigt meddeler Paulli sine læsere, at der inden længe ville komme prospekter af Landgangen ved Råå og landgangen ved Ystad samt grundrids af fæstningerne Karlshamn og Kristianopel. Ambitionerne virker helt overvældende, og den eneste forklaring på, at Paulli ønskede at udgive billeder fra disse tidlige faser af krigen, kan vel kun skyldes ønsket om at udgive et samlet billedværk om krigen. Men den begejstringsrus, der havde lammet danskerne under de indledende faser af krigen, kølnedes imidlertid efter nederlaget ved Lund i december 1676, og det kan vel være forklaringen på, at disse stik ikke blev sat i produktion.

I en oversigt over udgivne kobberstik fra december 1677 omtales rækken af publicerede kobberstik:
1) En "afridsning" af Wismar og Hvalfisken

2) Rügen

3) Skåne, Halland og Blekinge

4) Gotland

5) Vänersborg

6) Helsingborg

7) Landskrona

8) Kristianstad

Og samtidigt annonceres:

9) En afridsning af Marstrand og de derved liggende skanser Karlstad, Gustavsberg, Hedvigholm og Malepert.

10) Et prospekt af søslaget ved Møn 1.6.1676

11) Et prospekt af søslaget i Køge Bugt 1.7.1677

Listen er samtidigt den sidste 
omtale i Daniel Paullis aviser om illustrationerne, og af de tre planlagte stik kan kun afbildningen af Marstrand identificeres med sikkerhed ${ }^{4}$.

Det var således gået strygende: For Paullis billedudgivelser må ikke overraskende have vakt stor interesse blandt københavnerne, der med spændt forventning fulgte krigens gang, og som ikke ad andre kanaler kunne fă fat i billedmateriale om krigen.

\section{Forlæggene}

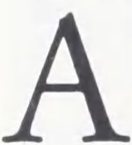

$\mathrm{f}$ de ialt 11 afbildninger falder prospektet af Wismar (nr. 1) helt uden for, kopieret som det er efter et ældre stik, hentet fra Matthäus Merians “Topographia Saxoniæ Inferiores” 1653. Også kortet over Rügen (nr. 2) kunne Paulli "låne" andetstedsfra, og det bygger på Eilhardt Lubbins kort over øen fra 1641 , udgivet af den nederlandske kartograf Jan Jansonnius. De øvrige kort og tegninger synes derimod at være nytegnet og udgivet for første gang af Daniel Paulli.

Til denne opgave indledte $\mathrm{Da}$ niel Paulli et samarbejde med tegneren og maleren Johan Huusman, som netop på denne tid udarbejdede kort og tegninger til Peder Hansen Resens "Atlas Danicus"s. På nær de to omtalte stik af Wismar og Rügen er de resterende syv stik (nr. 3-10) alle signeret af Johan Huusman med betegnelsen "Joh. Huusman fecit" eller "Joh. Huusman delineavit et fecit", det betyder direkte oversat, at han har "tegnet og gjort" de pågældende stik. Men det betyder ikke nødvendigvis, at Huusman selv har tegnet prospekterne og opmålt kortene. Datidens terminologi er netop så

Paulli/Huusmans kort over Gotland fra 1677. Gotland var 1676-1679 dansk provins.

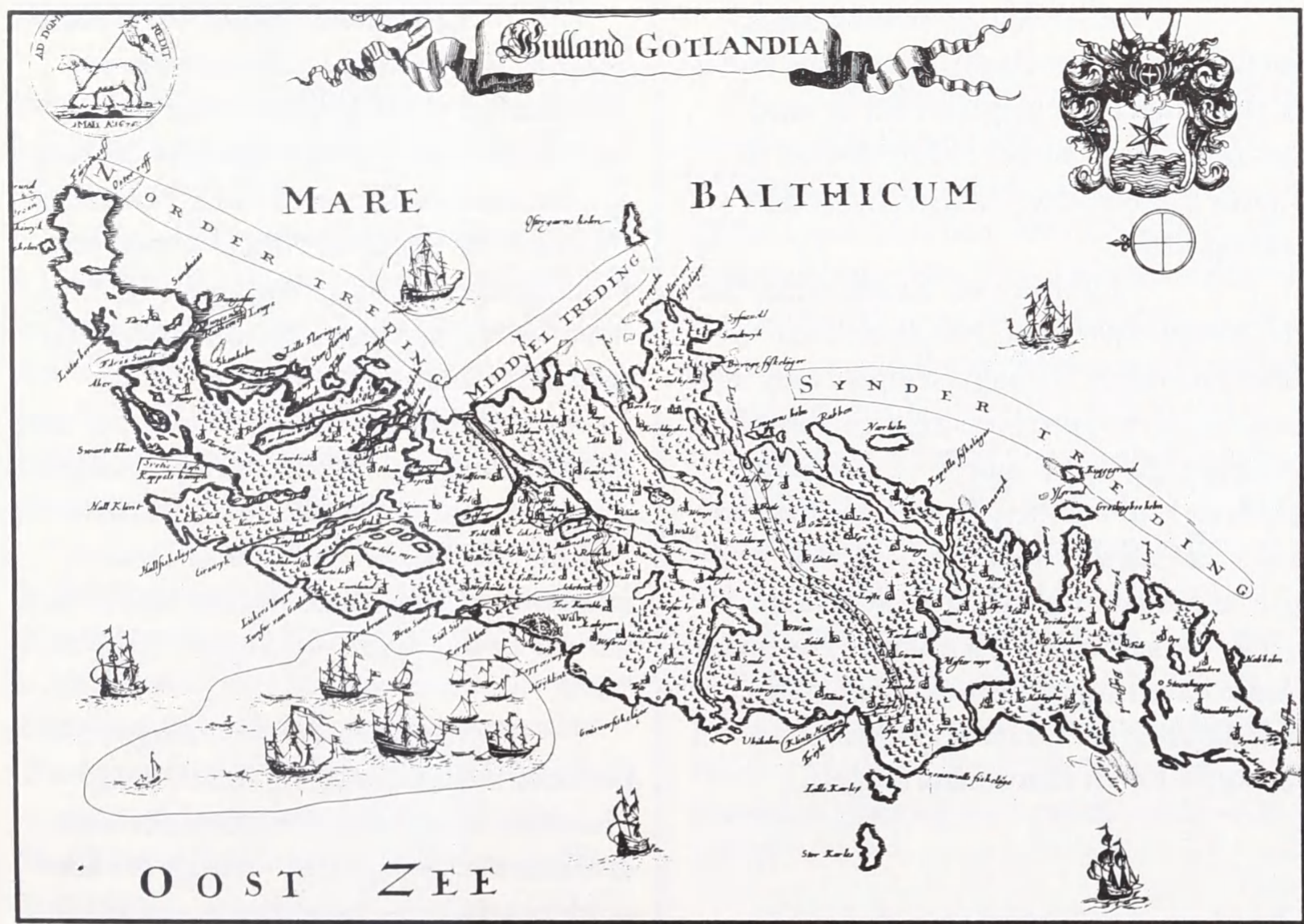


upræcis, at han med de benyttede vendinger ligeså godt kan have sammentegnet de mange forskelligartede forlæg, som Paulli havde fået fat i. Alt tyder på, at det forholder sig således, at Huusman var Paulliudgivelsernes billedredaktør, og at han således finpusede forlæggene og udarbejdede den rentegning, som kobberstikkerne kunne arbejde efter.

Dette viser således Huusmans store generalkort over Skåne, Halland og Blekinge fra 1677 , der bygger på en revideret udgave af den danske kartograf Johannes Mejers kort over landsdelene fra 1650 'erne. Forlægget er dog tydeligvis blevet revideret før udgivelsen.

Også Paulli-Huusmans kort over Gotland har sit udspring i ældre kort, idet man benyttede den svenske ingeniørofficer Johan Meyers kort over øen fra 1646, som man fra dansk side kan have fået fat $\mathrm{i}$ ved erobringen af Visby i $1676^{6}$.

Det er ikke på samme måde muligt at afdække Paulli/Huusmans kilder til de øvrige plancher, men det er sandsynligt, at de er blevet udført direkte på Paullis initiativ, etv. via hans meddelere i hær og flåde.

På kortet over Kristianstad, der har betegnelsen "Joh. Huusman fecit" tilføjes endvidere "L. Salm sculpsit", der altså betyder, at L. Salm har stukket kobberpladerne. At fecit, "gjorde", i denne forbindelse blot kan betyde, at Huusman har afsluttet et forberedende arbejde, vel nærmest en redaktion, følger umiddelbart heraf. De sejlivede myter, om at Huusman skulle have fungeret som kobberstikker, må således aflives. Det viser også andre forhold i Johan Huusmans biografi.
Johan Huusman

$\mathrm{H}$ an kom til København i 1667 og betegnedes da som "kontrefejer". I 1671 blev han tilknyttet Peder Hansen Resen, der netop i disse år indsamlede oplysninger til den store Danmarksbeskrivelse, som han ønskede at udstyre med afbildninger af købstæder og med landkort over provinserne. Til Resen tegnede Huusman efter egne oplysninger de fleste af grundridsene til Atlas Danicus, hvis billedside forelå færdig i 1677.

Ved Peder Hansen Resens mellemkomst var Huusman i 1673 blevet udnævnt til universitetskobberstikker. For en senere eftertid kan det derfor forekomme besynderligt, at han angiveligt ikke selv kunne udøve den sjældne kunst. Men det fremgår med al tydelighed af et indlæg i en sag om ophavsretten til stikningen af Abraham Wuchters portrætter, der nåede Højesteret? ${ }^{7}$.

Huusmans opgaver var derimod at holde liv i et kobberstikkerværksted, hvis menige medarbejdere skulle producere de stik, som Universitetet havde brug for, herunder stikkene til Peder Hansen Resens Atlas Danicus. Arbejdet med kobberstikningen til dette værk må i 1676 have været i fuld gang: Aktualitetshensyn medførte imidlertid, at kobberstikkerværkstedets produktion blev omlagt så det kunne tilfredsstille Paullis forlag med illustrationer, om krigen fik det forventede udfald. 1677-udgaven af "Atlas Danicus" indeholder netop Paullis stik af Gotland, der var en dansk provins i årene 16761679.

Selv uden denne tydelige forbindelse mellem Paulli og Resen med Huusman som mellemmand er det klart, at Huusmans øvrige stik - særligt stikkene af Helsingborg og Landskrona - stilistisk 


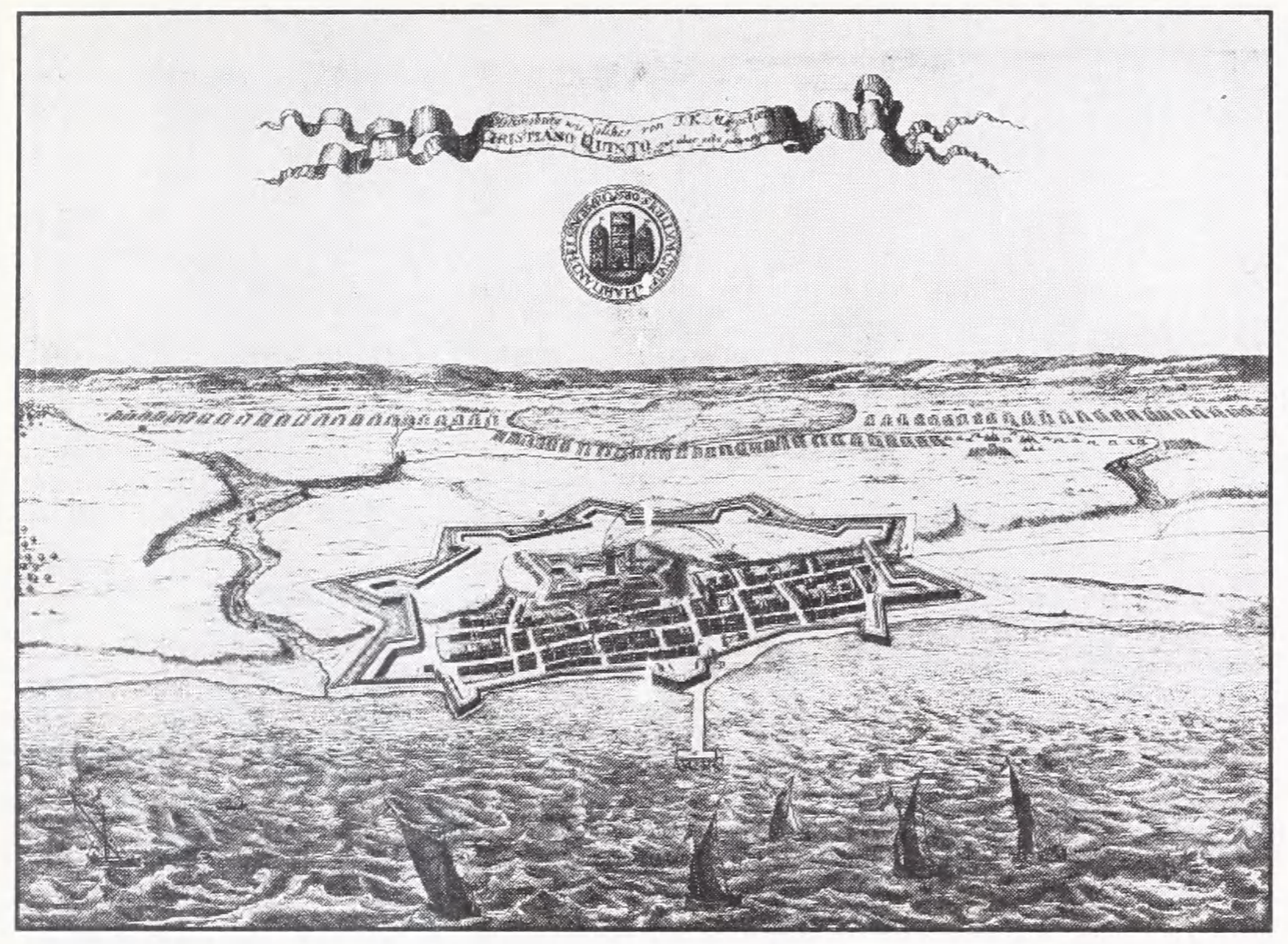

Prospekt af Helsingborg, Paulli/Huusman.

hører hjemme i den sammenhæng, hvori købstandsplanerne til Atlas Danicus blev skabt.

Efter Peder Hansen Resens død i 1688 fortsatte Huusman indsamlingen af billeder til Atlas Danicus, og han udgav i 1695 på egen hånd et nyoplag af plancherne, der viser, at han endnu på dette tidspunkt kunne disponere over kobberpladerne fra Resens værk.

Til samme kreds af kort og billeder synes også en afbildning af Slaget $\mathrm{i}$ Køge Bugt 1. juli 1677 at høre: Det er også signeret af Johan Huusman, der her både har rentegnet og udgivet prospektet (betegnet som "fecit og excudit"). Måske er dette stik identisk med det, Daniel Paulli nævner i sit avis i december 1677 (nr. 11).
Et stort, anonymt, dobbeltblad, der viser den danske flåde, der ligger ved Sjællandskysten parat til afsejling mod Skåne i juni 1676 kan formodentligt også tilskrives Huusman. Det adskiller sig imidlertid stilistisk noget fra Paullis øvrige udgivelser, og kan derfor være et selvstændigt arbejde fra Huusmans side. Ved en misforståelse har det tidligere været betegnet "Landgangen ved Råå", selvom det tydeligt viser den danske flåde liggende for anker ved den sjællandske Øresundskyst med Skåne i baggrunden. Som et kuriosum kan det iøvrigt nævnes, at de to originale kobberplader til flådeopmarchen er bevaret til vore dage. De befinder sig i Rosenborgsamlingen, hvor de blev fundet $\mathrm{i}$ $1926^{8}$. 


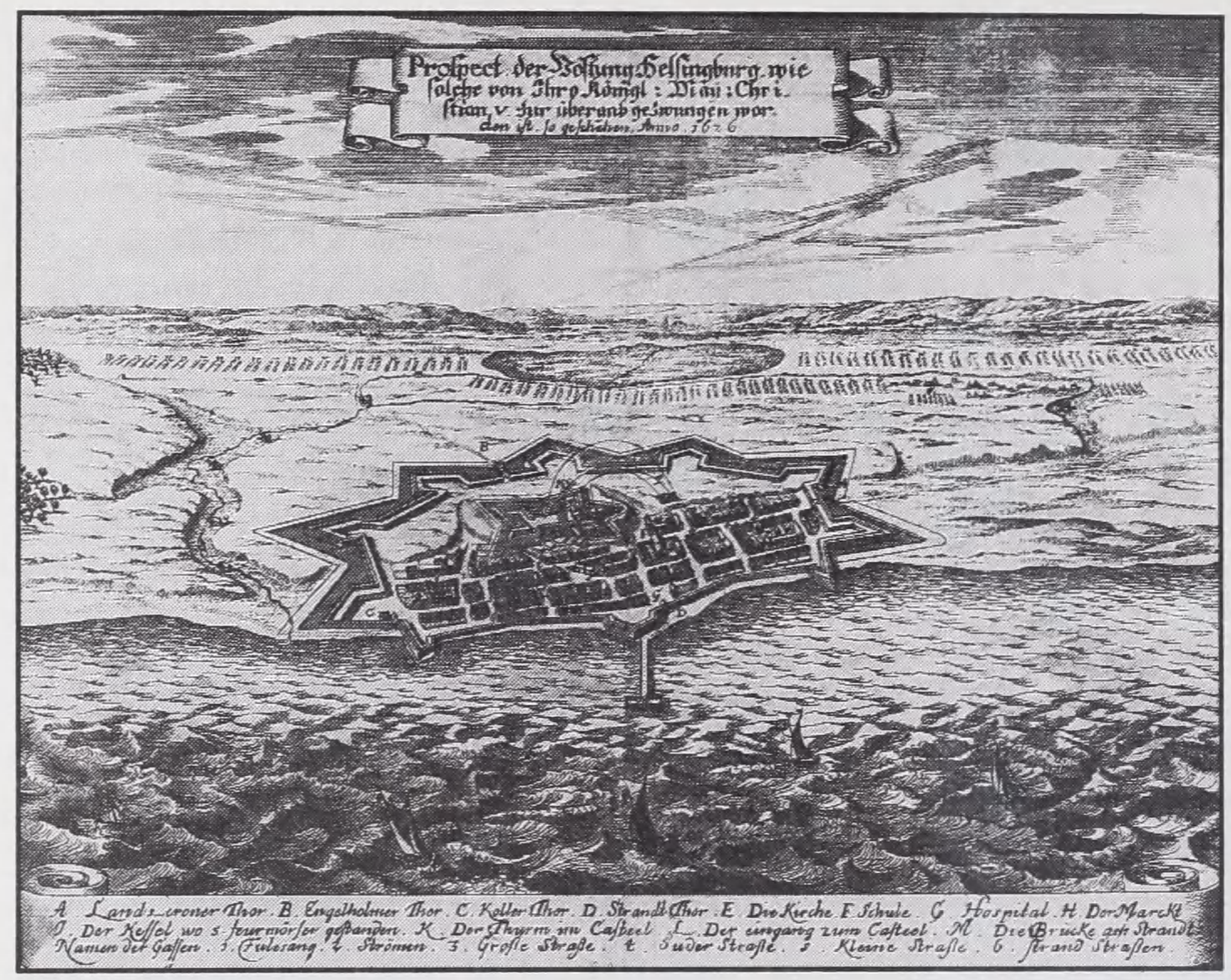

Prospekt af Helsingborg. Andreas Müller, Amsterdam 1683.

\section{Genbrug og efterstikninger}

elvom man må tro, at oplaget af

S Daniel Paullis udgivelser har været ganske pænt, er de kun bevaret i ganske få exemplarer. Få år senere dukker flere af kobberstikkene op $i$ en variantudgave i Andreas Müllers samtidshistoriske krønike "Des Verwirrten Europæ Dritter Theil", udgivet i Amsterdam i 1683. Her indgår Paullis prospekter over Helsingborg, Landskrona og Kristianstad samt kortet over Vänersborg som planchebilag. Det er naturligvis ikke overraskende på et tidspunkt, der ikke kendte begrebet ophavsret, men det er bemærkelsesværdigt, at Müller ikke blot har ladet Paullis stik kopiere, men tværtimod har făet fat i de fire originale kobberplader, som han så har ladet beskære kraftigt i siderne, for at passe dem ind formatet på sin egen udgivelse. Derved forsvandt behændigt Huusmans og Paullis navne. Originalbladene var også for høje, og næsten 1/3-del af den øverste del af pladen blev skåret væk. Dermed forsvandt de karakteristiske indskriftbånd, og Andreas Müller måtte lade en ny titel stikke. Den blev anbragt lige under øverste kant, og Müllers stik virker derfor noget sammenpressede i forhold til de velproportionerede originaler.

Hvorledes Andreas Müller har fået fat i Paullis plader, vides ikke, men Paulli havde en filial i Frankfurt am Main, og dér kan han have solgt pladerne, da krigen var slut og salgsmulighederne i Danmark var udtømt.

En regulær kopi af Paullis stik møder vi derimod hos Matthäus Merian- 


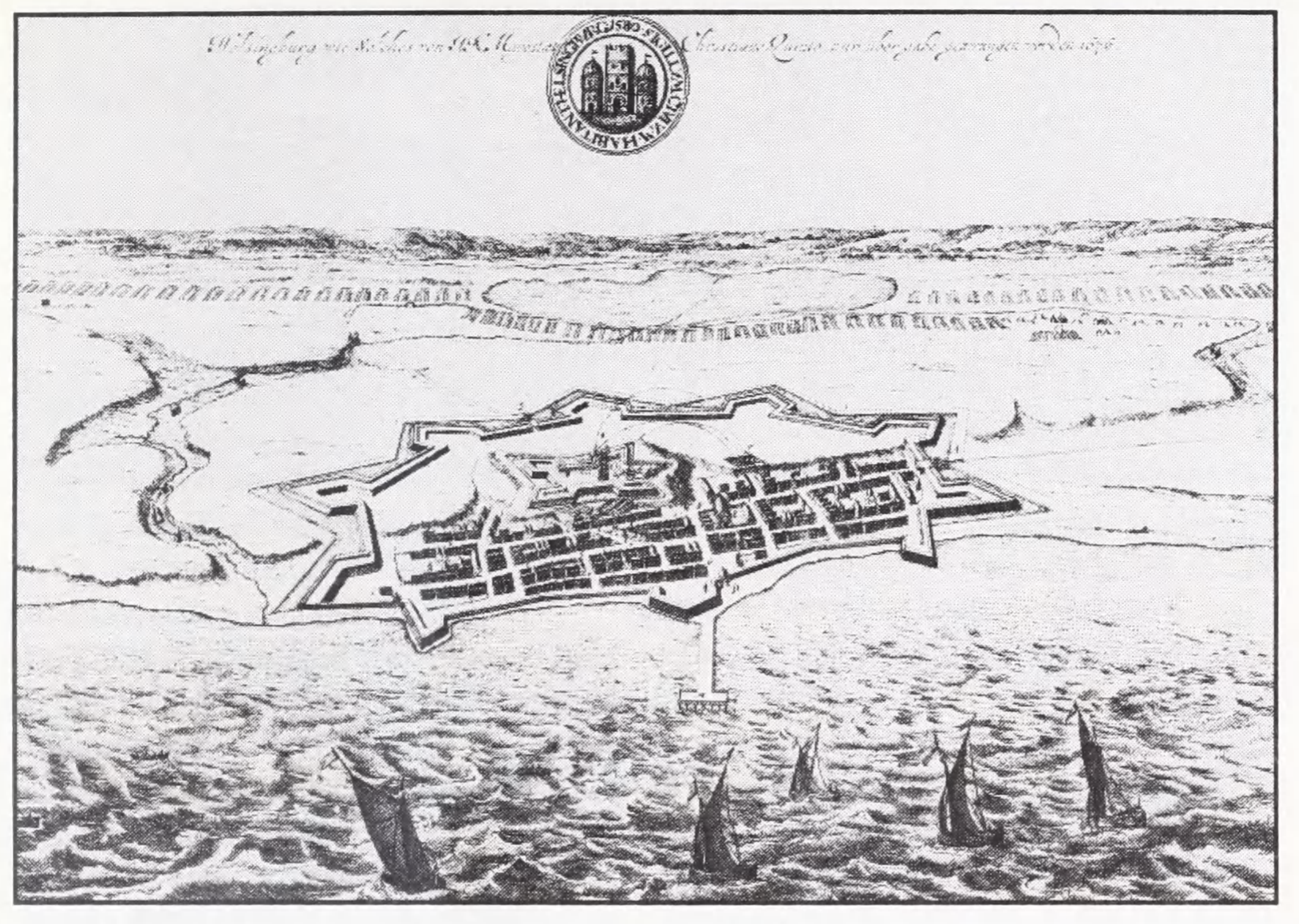

Prospekt af Helsingborg. Matthäus Merina-forlaget, 1687.

forlaget, der i 1687 udgav 11. bind af samtidsjournalen "Theatrum Europæum", der dækkede perioden 1672-79, og hvor en afbildning af skånske krigs begivenheder jo var uundværlige. Merian lod Paullis originalplancher efterstikke så godt som man formåede. Forlaget havde jo lange traditioner for topografiske billedgengivelser, så resultatet blev flot. Blot ændrede man index og titelfelt, som man placerede på et karakteristisk oprullet skriftbånd.

Merian har uden tvivl fået fat på sine forlæg via Paullis filial i Frankfurt. Huusmans stik fik en lang eftertid. Allerede i slutningen af 1670 'erne benyttedes stikkene som forlæg for et topografisk kort. På Kungliga Biblioteket findes et anonymt og udateret lille værk
"Beschreibung der Länder Schonen, Halland und Blecking", udgivet engang $\mathrm{i}$ slutningen af $1670^{\prime}$ 'erne. På disse kort har man blot teget den del af det oprindelige motiv, der berørte selve byområdet. Omegnen har der ikke været plads til, så den har man så lagt groft ind som et bikort i et hjørne. Hvem der har stået for denne udgivelse eller kortene, vides som omtalt ikke, men udgangspunktet må have været Paullis originalstik.

Endnu engang skulle Daniel Paullis stik blive benyttet af en topografisk forfatter: Omkring 1700 udgav den amsterdamske topograf J. Ottens et blad med de fire prospekter af de svenske byer med en tysk/fransk dobbelttext. Bladet har vistnok været beregnet på at blive klippet fra hinanden $\mathrm{i}$ sine fire dele og klistre ind 


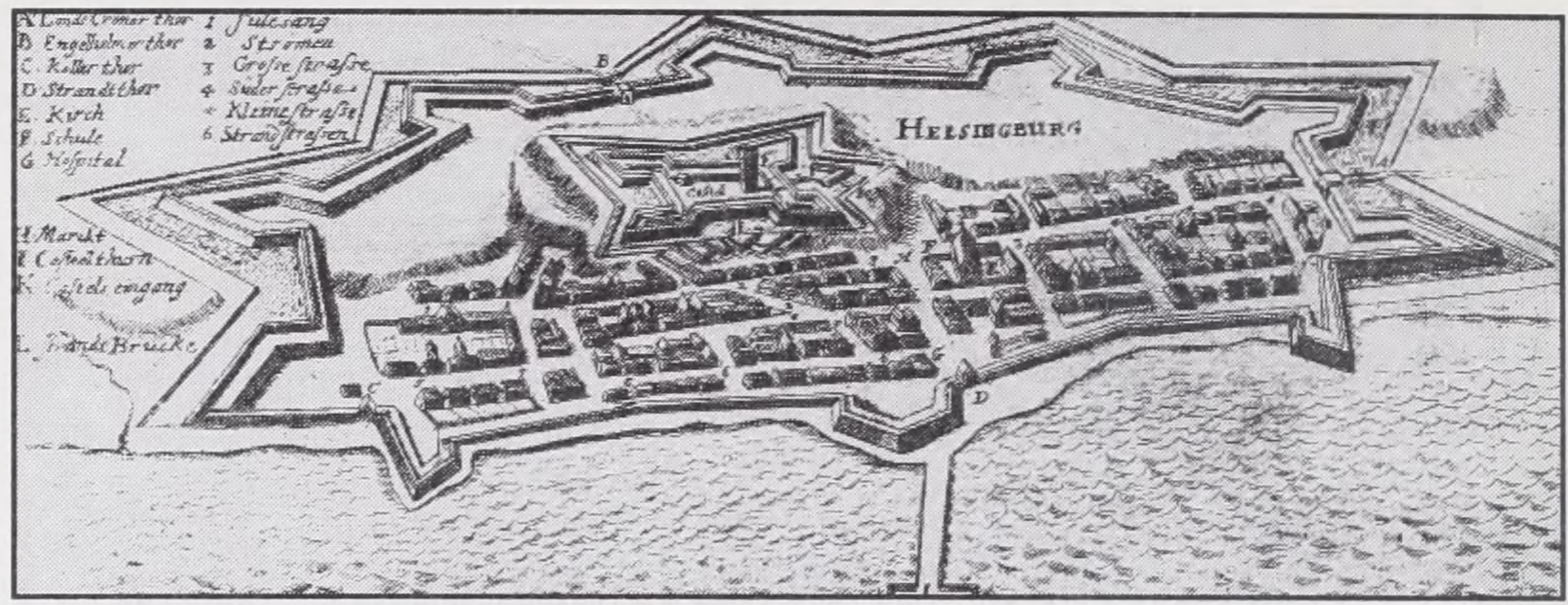

Prospekt af Helsingborg. Fra "Beschreibung der Länder Schonen, Halland und Blecking". Slutningen af 1670'erne. Kungliga Biblioteket, Stockholm.

på et kort over Skåne, som Ottens også havde udgivet.

Endeligt udgav den unge artillerikaptajn Moritz Friedenrich i 1765 sin Christian den 5.s krigshistorie med fire afbildninger, stukket af I. Haas efter Friedenreichs kopier af Paullis stik (eller måske en af de mere talrige kopier efter dem? Friedenreichs prospekter er stærkt udvandede i forhold til Paullis originalkort.

Selvom Daniel Paullis og Johan

Noter

1 B. Steckzén og N. Wilmarsson: Erich Dahlberghs betaljplaner. Stockholm 1922.

2 P. Stolpe: Dagspressen i Danmark, 2. bind, 1879 , s. [96]-205 ; Jette D. Søllinge og Niels Thomsen: De danske aviser 16341689, bind 1, 1988, s. 79-80.

3 Bjørn Westerbeek Dahl: Johan Huusman og kobberstikket af Helsingborgs erobring i 1676, i: Kring Kärnan 1986, s. 35-58, ill. jf. samme i: Weilbach. Dansk Kunstnerleksikon, 4. udgave, 3. bind, 1995, s. 430.

4 Extraordinaire Relation 1676, s. 1064 (12.8.), s. 1112 (19.8.), s. 1128 (21.8.), s. 1192 (2.9.), s. 1448 (24.10.). - I Danske Afdelings ene exemplar af "Extraordinære
Huusmans stik var beregnet på øjeblikkets behov, blev de igen og igen kopieret og tilpasset de nye udgiveres aktuelle ønsker. I Müllers, Merians, Ottens og Friedenreichs gengivelser levede de originale kort videre og fik en langt større udbredelse end han kunne have drømt om ved udgivelsen. Til gengæld drukende de originale kort $\mathrm{i}$ mængden af 2. og 3. rangs kopieringer, og det fortjener Paullis og Huusmans smukke arbejde på ingen måde.

Maanedlige Relationer" findes flere af stikkene indfalset. - Hvor intet andet er nævnt i de følgende, er lokaliseringen af stikkene Det Kongelige Biblioteks Kortsamling.

5 Som note 3.

6 N. E. Nørlund: Danmarks Kortlagning. I, 1942, s. 54 og planche 56.

7 Som note 3 ; Poul Eller: Kongelige Portratmalere i Danmark 1630-82, 1971, s. 357.

8 Aksel Christensen: Romeyn de Hooghes Kobberstik af Svenske-Krigen 1675-1679, i: Samleren, 3. Aargang, 1926, s. 216-217.

9 Moritz Friedenreich: Kong Christian den Femtes Krigs-Historie, 1. bind, 1758. 